\title{
Inhibition study of proinflammatory factor with ethanolic extract of propolis on innate immunity from diabetes mellitus mice model
}

\author{
Bambang Pristiwanto, ${ }^{1}$ Sutiman B. Sumitro, ${ }^{2}$ Muhammad S. Djati, ${ }^{2}$ Aris Soewondo, ${ }^{2}$ Hideo Tsuboi, ${ }^{3}$ \\ Muhaimin Rifa'i ${ }^{2}$ \\ ${ }^{1}$ Biology Master Program, Brawijaya University, Malang, Indonesia; ${ }^{2}$ Biology Department, Brawijaya University, \\ Malang, Indonesia; ${ }^{3}$ Unit of Environmental Health Sciences, Department of Biomedical Sciences, College of Life and \\ Health Sciences, Chubu University, Kasugai-shi, Aichi, Japan
}

\begin{abstract}
Health becomes an important topic today. One current problem was how to treat the effects of metabolic diseases, such as diabetes mellitus (DM). Thus, this study used an ethanolic extract of propolis (EEP), to test their ability as the supplement in the diabetes treatment to reduce inflammation, through proinflammatory factor response, especially nuclear factor $\kappa \mathrm{B}(\mathrm{NF}-\kappa \mathrm{B})$. The streptozotocin-induced diabetes mellitus (SID) mice model was used, and expression of an proinflammatory factor was analyzed in their
\end{abstract}

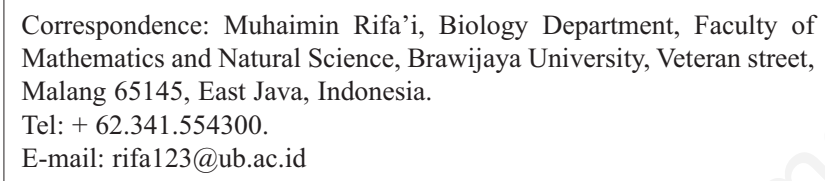

Key words: B cell; diabetes mellitus; macrophage; Nuclear Factor-кB; proinflammatory cytokines.

Contributions: the authors contributed equally.

Conflict of interest: the authors declare no potential conflict of interest.

Funding: the work was supported by National Strategic Research (Indonesia) through name Prof. Muhaimin Rifa'i, Brawijaya University.

Clinical trials: the study is registered in the Ethics Committee that conducted by Research Ethic Comission, Brawijaya University, Indonesia (identifier no. 460-KEP-UB).

The author would like to thank to all staffs at Animal Physiology Laboratory, Biology Department, Mathematic and Natural Science Faculty, Brawijaya University for chemicals and instrumental facilities.

Received for publication: 31 March 2017.

Revision received: 13 July 2017.

Accepted for publication: 18 July 2017.

CCopyright B. Pristiwanto et al., 2017

Licensee PAGEPress, Italy

Journal of Biological Research 2017; 90:6733

doi:10.4081/jbr.2017.6733

This article is distributed under the terms of the Creative Commons Attribution Noncommercial License (by-nc 4.0) which permits any noncommercial use, distribution, and reproduction in any medium, provided the original author(s) and source are credited. innate immunity cells with 3 doses of EEP, i.e. $50 \mathrm{mg} / \mathrm{kg}$ body weight, $100 \mathrm{mg} / \mathrm{kg}$ body weight, and $200 \mathrm{mg} / \mathrm{kg}$ body weight. Treatment of EEP in SID with three doses treatment decrease the number of macrophages with NF- $\mathrm{B}$ B expression significantly with $\mathrm{DM}$ control group. The results of $\mathrm{B}$ cells with $\mathrm{NF}-\kappa \mathrm{B}$ expression showed that EEP treatment in SID could decrease in dose 1 and dose 3 , but not in dose 2 . Proinflammatory cytokines expression of macrophage, especially Tumor Necrosis Factor- $\alpha$ and Interferon- $\gamma$, with EEP treatment in SID could decrease in three doses. This study suggests that EEP could reduce inflammation by inhibiting the development of NF- $\mathrm{KB}$ in innate immunity cells.

\section{Introduction}

Health becomes an important topic today. One of the current problem mostly found was to treat the effects of metabolic diseases, such as diabetes. The disease is characterized by hyperglycemia or elevated blood sugar levels, or more commonly referred to diabetes mellitus (DM). DM are classified into two types based on causing factors, namely, type $1 \mathrm{DM}$ and type $2 \mathrm{DM}$. Type $1 \mathrm{DM}$ is characterized by events when insulin levels are low due to abnormalities in insulin secretion, and histologically it can be seen as a loss of insulin-producing beta cells of Langerhans islets in the pancreas. So this type is also called insulin-dependent DM. Type 2 DM occurs due to events of insulin resistance, which can also be combined with reduced insulin secretion. Type $2 \mathrm{DM}$ is the most common one. ${ }^{1}$ Global prevalence of DM, in 2014, reached $8.5 \%$ in adults with age $>18$ years risen from $4.7 \%$ in 1980 . An estimated 1.5 million deaths occurred due to DM and another 2.2 million deaths were attributable to high blood glucose in $2012 .^{2}$

The immune system in the occurrence of DM also plays a role by inflammatory response. The inflammatory response through role of Nuclear Factor- $\kappa \mathrm{B}(\mathrm{NF}-\kappa \mathrm{B})$, especially those driven by macrophages, is response to a loss of barrier function. ${ }^{3} \mathrm{NF}-\kappa \mathrm{B}$ has been considered a prototypical proinflammatory signaling pathway, the activation of $\mathrm{NF}-\kappa \mathrm{B}$ largely by proinflammatory cytokines, and then expressing of other proinflammatory cytokines, as Tumor Necrosis Factor- $\alpha$ (TNF- $\alpha$ ) and Interferon- $\gamma$ (IFN- $\gamma$ ). ${ }^{4}$ The immune system is useful to maintain the body condition against foreign substances, such as pathogens, which may be a risk factor for DM, especially in aggravating the inflammation. ${ }^{5}$ Thus, immunomodulatory applications in diseases related to the immune system balance are needed.

Natural substances for a supplement of treatment as an immunomodulator can be a solution to reduce the use of synthetic 
drugs. Propolis is product from honeybee that have broad spectrum of biological properties. ${ }^{6}$ Propolis is prepared by the honeybees to seal the cracks, smooth walls, and to keep moisture and temperature stable in the hive all year around. Propolis is a resinous substance used by bees as a coating to protect the honeycomb. ${ }^{7}$ Propolis have varies composition depend on the source. Generally, it is composed by $50 \%$ resin and vegetable balsam, $30 \%$ wax, $10 \%$ essential oil and aromatics, $5 \%$ pollen, and $5 \%$ other substances. ${ }^{8}$ Barbarić et al. ${ }^{9}$ were able to identify some phenolic acids and flavonoids that analyzing ethanolic extracts of propolis (EEP) by the RP-HPLC. From protection function of propolis, then it is considered to benefit the development of immune system homeostasis and disease recovery, particularly DM.

The aim of this study was to test the inhibition ability of ethanolic extract of propolis as a supplement in DM treatment to reduce proinflammatory factor that causing inflammatory response by innate immunity cells in DM mice model.

\section{Materials and Methods}

Propolis was collected manually from the beehive of the wasps ranch in Malang, East Java, Indonesia, and was kept desiccated pending its processing. It was extracted in $95 \% \mathrm{v} / \mathrm{v}$ ethyl alcohol, with extracting procedure suggested. ${ }^{10}$

Experimental animals were mice (Mus musculus) strain $\mathrm{Balb} / \mathrm{c}$, seven weeks old. Five animals were in a healthy and 20 animals in DM condition, with weight \pm 20 grams. Animal models of diabetes were streptozotocin-induced DM (SID) intraperitoneally in neonatal mice aged seven days, at a dose of $100 \mathrm{mg} / \mathrm{kg}$ Body Weight (BW). The concentration of streptozotocin (STZ) stock solution was $7 \mathrm{mg} / \mathrm{mL}$, by dissolving $7 \mathrm{mg}$ powder STZ with $1 \mathrm{ml}$ of $0.1 \mathrm{M}$ citrate buffer $\mathrm{pH} 4.5$. By assuming each baby's mice weight \pm 3.5 grams, then STZ was injected to obtain the desired dose is $50 \mu \mathrm{L}$. The injected mice were allowed to grow in the animal chamber, got feeding, drinking, as well as the replacement of the cage chaff done routinely. After five weeks old, the mice's blood glucose levels were measured with a glucometer. Blood glucose levels $>200 \mathrm{mg} / \mathrm{dL}$ showed that these mice have successfully induced DM. ${ }^{11}$ SID mice model were used because STZ can damages pancreatic $\beta$ cells, to resulting in symptoms of hyperglycemia. ${ }^{12}$

Mice which were determined to have symptoms of diabetes were used as a DM control group and the group with EEP treatment, it was divided into three group of doses treatment. That doses included dose 1 (50 mg/kg BW), dose 2 (100 mg/kg BW), and dose 3 (200 mg/kg BW). These doses were selected according to other experimental studies. The EEP treatment was orally carried out for 14 days. The healthy mice were used as normal control group. Each group consists of five mice. In for 14 days of treatment, it was followed by the measurement of blood glucose levels every three days for all group. Periodic measurements determined the effect of EEP to lower glucose levels in the blood plasma.

Animals were used in surgery to take the spleen. Then, the organ was crushed in a phosphate-buffered saline (PBS) solution and transferred to $15 \mathrm{~mL}$ polypropylene tube. It was centrifuged at $2500 \mathrm{rpm}$, in temperature $10^{\circ} \mathrm{C}$, for 5 minutes. Results of supernatant were discarded, and pellets were formed to be resuspended with $1 \mathrm{~mL}$ PBS. ${ }^{13}$ Results of resuspension were moved $5 \mu \mathrm{L}$ at 1.5 $\mathrm{mL}$ microtube, added $95 \mu \mathrm{L}$ of Evans blue and homogenized. Cells were then calculated by hemocytometer under microscope observation.
Resuspension of cell isolation was added with $100 \mu \mathrm{L}$ in a microtube containing $300 \mu \mathrm{L}$ of PBS, then centrifuged at 2500 $\mathrm{rpm}$, in temperature $10^{\circ} \mathrm{C}$, for 5 minutes. The supernatant was discarded, the pellets were formed then added with $1 \mu \mathrm{L}$ of antibody (for detection of cell surface molecules) which had been diluted with $50 \mu \mathrm{L}$ PBS. The suspension was incubated in an ice box for 20 minutes. ${ }^{13}$ Furthermore, the cell suspension was added to $50 \mu \mathrm{L}$ fixation buffer (BioLegend), and it was incubated in the ice box for 20 minutes. Next, the cell suspension was added to $500 \mu \mathrm{L}$ of intracellular staining permeabilization wash buffer (1X) (BioLegend) and centrifuged at $2500 \mathrm{rpm}$, in $10^{\circ} \mathrm{C}$, for 5 minutes. Supernatant was discarded, pellets were formed then added with $1 \mu \mathrm{L}$ of antibody (for detection of intracellular molecules) which had been diluted with $50 \mu \mathrm{L}$ PBS. ${ }^{14}$ The type of immunological staining was a triple staining, the dye was Fluorescein Isothiocyanate (FITC)conjugated rat anti-mouse CD68 (clone: FA-11 / BioLegend), Phycoerythrin (PE)-conjugated rat anti-mouse B220 (clone: Poly4053 / BioLegend), Phycoerythrin-cyanine dye 5 (PE/Cy5)conjugated rabbit anti-mouse NF- $\kappa \mathrm{B}$ (Polyclonal / Bioss). In addition, it is also used FITC-conjugated rat anti-mouse CD68 (clone: FA-11 / Biolegend), PE-conjugated rat anti-mouse TNF- $\alpha$ (clone: MP6-XT22 / Biolegend), PerCP/Cy5.5-conjugated rabbit antimouse IFN- $\gamma$ (clone: XMG1.2/ Biolegend) to analyze the expression of macrophage's cytokine.

Immunostaining results were then added with $400 \mu \mathrm{L}$ sterile PBS and put in a cuvette flow cytometer. The cuvette was mounted on a BD FACS Calibur ${ }^{\mathrm{TM}}$ nozzle flow cytometer. It performed setting on a computer with software BD Cell Quest Pro ${ }^{\text {TM }}$ (San Jose, CA) and performed connection with the flow cytometer (Acquiring mode).

Data were analyzed by using the modeling results of calculating cells which expressing NF- $\mathrm{KB}$ and proinflammatory cytokines was observed with BD Cell Quest Pro ${ }^{\mathrm{TM}}$ software. They were tested statistically to obtain the normality and homogeneity of variance test. The data were then tested by one-way ANOVA with $\alpha$ value $=0.05$. Then posthoc Tukey HSD (Honestly Significant Difference) test was performed to determine the difference when the ANOVA results showed significant results. Data analysis was conducted by SPSS 16.0 for Windows.

\section{Results}

\section{The number of macrophages (CD68) cell with NF- $\kappa$ B expression}

Results of each treatment were shown by the absolute number of macrophage (CD68) cells to express NF- $\mathrm{kB}$, from whole living cells in the sample (Figure 1A). The relative number of macrophage cells to express NF- $\mathrm{BB}$ from each treatment was shown by flow cytometry dot plot, from whole living cells in the sample (Figure 1B). The results of SID mice model revealed that significantly increased the number of macrophage cells expressing inflammatory factors $(\mathrm{NF}-\mathrm{\kappa B})$ to the normal control group $(\mathrm{P} \leq 0.05)$.

The absolute number of macrophage with NF- $\kappa \mathrm{B}$ expression in the treatment group (DM_50, DM_100, and DM_200) was significantly different $(\mathrm{P} \leq 0.05)$ with $\mathrm{DM}$ control group. The results showed that the compounds in EEP could act as an inhibitor to NF$\kappa \mathrm{B}$ expression in macrophage cells. In addition, the treatment group was also not significantly different $(\mathrm{P}>0.05)$ with a healthy control group. It showed that the EEP was able to restore NF- $\mathrm{BB}$ 
expression in the macrophage cells to reach normal levels. The results demonstrated that treatment EEP on SID with three doses used showed a decrease in the number of macrophages with NF$\kappa \mathrm{B}$ expression significantly with DM control group. Furthermore, it showed that at the lowest dose, the EEP was able to inhibit the expression of NF- $\mathrm{kB}$ in macrophage cells.

\section{The number of B cell with NF- $\mathrm{kB}$ expression}

Results of each treatment were shown by the absolute number of B cell (B220) to express NF- $\kappa$ B, from whole living cells in the sample (Figure 2A). The relative number of B cell to express NF$\kappa \mathrm{B}$ from each treatment was shown by flow cytometry dot plot, from whole living cells in the sample (Figure 2B). The results of SID mice model revealed that the significant increase was in the number of B cell expressing NF- $\kappa \mathrm{B}$ compared with normal control group $(\mathrm{P} \leq 0.05)$.

The absolute number of B cell with NF- $\mathrm{BB}$ expression from the treatment of EEP in SID mice model showed that at doses 50 and $200 \mathrm{mg} / \mathrm{kg} \mathrm{BW}$ significantly different $(\mathrm{P} \leq 0.05)$ with $\mathrm{DM}$ control group, and no significantly different $(\mathrm{P}>0.05)$ with a healthy control group. However, the EEP at a dose of $100 \mathrm{mg} / \mathrm{kg} \mathrm{BW}$ was not significantly different from the two controls group. The results

A

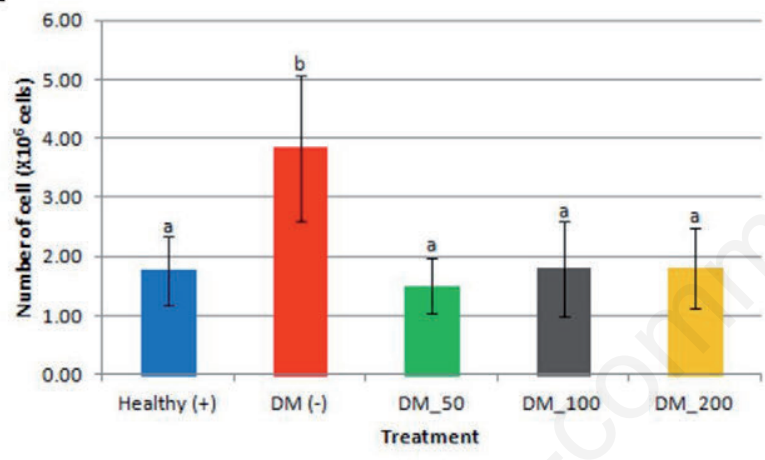

B

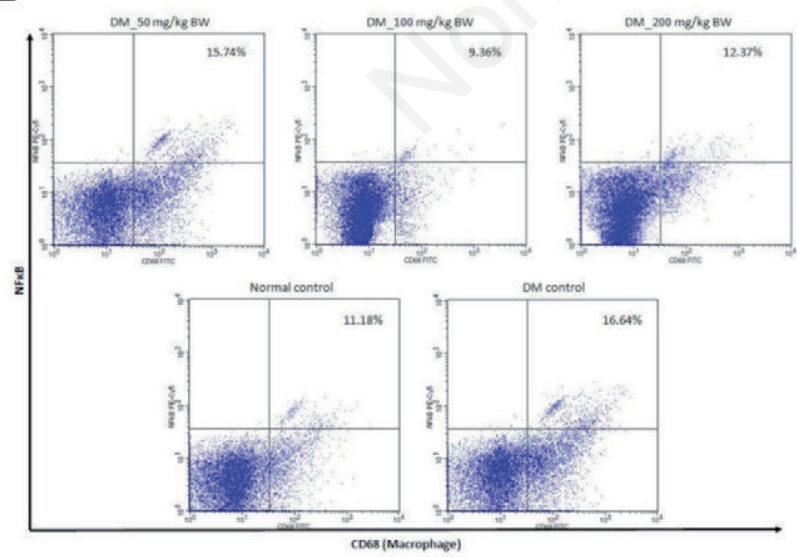

Figure 1. A) Absolute number; B) Relative number of macrophage cells with $\mathrm{Nf} \kappa \mathrm{B}$ expression in each treatment. Note: Healthy $(+)=$ normal control; DM $(-)=$ DM control; DM $\_50=D M$ with 50 $\mathrm{mg}$ EEP/kg BW; DM_100=DM with $100 \mathrm{mg}$ EEP/kg BW;

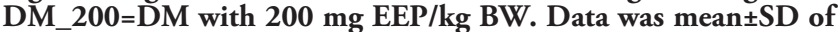
each group. The common different letter above the bar indicate significantly different at $\mathrm{P}$-level $=5 \%$. showed that the compounds in EEP could act as inhibitors of NF$\kappa \mathrm{B}$ expression of $\mathrm{B}$ cell in lowest dose.

\section{The number of macrophage cell with cytokines expression}

Results of each treatment were shown by the absolute number of macrophage cell with their proinflammatory cytokines (TNF- $\alpha$ and IFN- $\gamma$ ) expression from whole living cells in the sample (Figure 3A). The relative number from each treatment was shown by flow cytometry dot plot of macrophage cell, from whole living cells in the sample, to express TNF- $\alpha$ (Figure 3B) and IFN- $\gamma$ (Figure 3C). The results of SID mice model revealed that the significant increase was in the number of B cell expressing NF- $\kappa \mathrm{B}$ compared with normal control group $(\mathrm{P} \leq 0.05)$.

Result of macrophage cell which express both of cytokines showed a significant increase in DM control group as compared to normal control group $(\mathrm{P} \leq 0.05)$. Furthermore, the treatment of the EEP in SID mice model, even on the three doses shown significantly declined against DM control group. It shows an inhibition of the cytokines expression that support has occurred inhibition of transcription factors that lead to the expression of these cytokines.

A

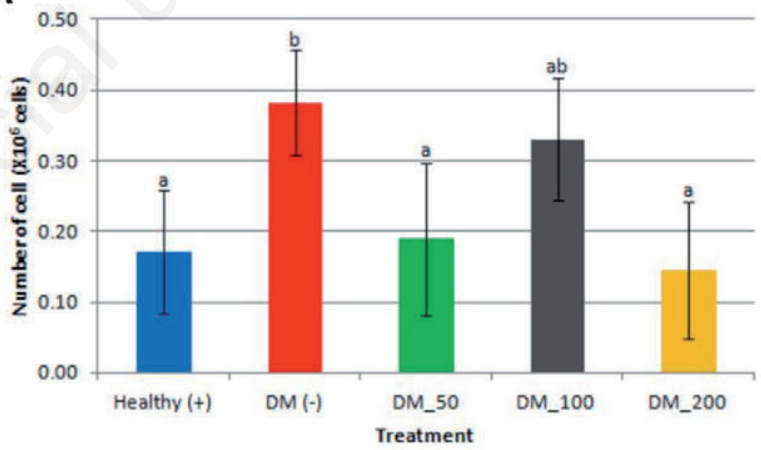

B

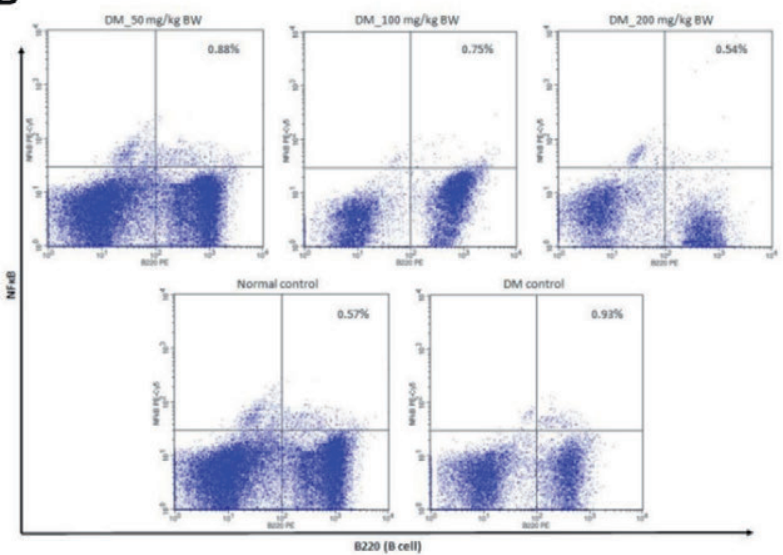

Figure 2. A) Absolute number; B) Relative number of $B$ cell with NfikB expression in each treatment. Note: Healthy $(+)=$ normal control; DM (-)=DM control; DM_50=DM with $50 \mathrm{mg} \mathrm{EEP} / \mathrm{kg}$ BW; DM_100=DM with $100 \mathrm{mg}$ EEP/kg BW; DM_200=DM with $200 \mathrm{mg} \mathrm{EEP} / \mathrm{kg} \mathrm{BW}$. Data was mean \pm SD of each group. The common different letter above the bar indicate significantly different at $\mathrm{P}$-level $=5 \%$. 


\section{Discussion}

Macrophage was the first defense against the antigen in the inflammatory mechanisms. Thus, the increased expression of inflammatory factors $(\mathrm{NF}-\mathrm{\kappa B})$ demonstrated that inflammatory responses in individuals with $\mathrm{DM}$ have occurred in its body. ${ }^{15} \mathrm{~A}$ decrease of NF- $\mathrm{kB}$ expression level by macrophage cells in the treatment group was suspected due to flavonoids contained in EEP. It showed that at the lowest dose, the EEP was able to inhibit the expression of NF- $\mathrm{KB}$ in macrophage and suspected compound was the containing flavonoids which play a role in it. It was supported by other studies, that Luteolin, class of flavonoids which can inhibit lipopolysacharide (LPS) -induced NF- $\kappa B$ activation in macrophage cells. ${ }^{16}$

The process of forming inflammation in DM by B cell is also detected as the research conducted, ${ }^{17}$ and it supported the process of increasing the number of $\mathrm{B}$ cell through proliferation pathways affected by NF- $\kappa \mathrm{B} .{ }^{18}$ The proinflammatory transcription factor, $\mathrm{NF}-\mathrm{\kappa B}$ especially, in $\mathrm{B}$ cell had different roles, in addition to the expression of proinflammatory cytokines. In B cell, NF- $\kappa \mathrm{B}$ also contributed to the regulation of cell division which had matured. The cleavage arrangement occurred in the G0 until the end of G1, where at this stage of cell cycle, it is a process of forming the ribosome, that was essential for DNA replication. ${ }^{19}$ The control of cell growth was the dependent $\mathrm{NF}-\mathrm{kB}$ activation which was also required for all signals, including as an inducer of the expression for c-Myc in the cell division. The presence of c-Myc transgenic is not sufficient to generate a signal of dependent mitogen proliferation of B cell. ${ }^{18}$ When there is no presence of B cell in the inflammatory process which occurs in mice with symptoms of DM/obese mice, a role of $\mathrm{B}$ cell that suppress the presence of regulatory $\mathrm{T}$ cells (Tregs) can be seen. It was characterized by an increase of Tregs and reduced inflammation in obese mice which did not have $\mathrm{B}$ cell compared obese mice with the presence of $\mathrm{B}$ cell in that studies. It showed the role of B cell supports the function of proinflammatory $\mathrm{T}$ cell in obesity. ${ }^{17}$ It was also supported by a recent study in Tregs, that EEP administration dose $200 \mathrm{mg} / \mathrm{kg}$ BW in DM mice model showed changes in the number of Tregs as in healthy control group. ${ }^{20}$ In addition, Tregs could prevent an increase of activated T cells, ${ }^{21}$ which can lead to symptoms of DM. A decrease in the number of $\mathrm{B}$ cell through the proliferation response of NF- $\mathrm{\kappa B}$ was also a factor in controlling the pathogenicity of DM. In dose $2(100 \mathrm{mg} / \mathrm{kg} \mathrm{BW})$, the number of B cell with $\mathrm{NF}-\kappa \mathrm{B}$ decrease not significantly different from DM control group (Figure 2A). The condition may occur because the amount of EEP that suppresses NF- $\mathrm{KB}$ activation is not as large as the amount of antagonist compound, which is able to activate NF- $\mathrm{BB}$ at that dose. The similar conditions occured in TNF- $\alpha$ expression by macrophages, which have decreased the expression not significantly of the DM control group. This is because the herbal or similar extracts have been shown to modulate immune responses during inflammation depending on its dose. ${ }^{22}$

The suspected compounds that playing a role in the response were phenolic and flavonoids which became one of the ingredients in propolis. Both compounds have a role in inhibiting NF- $\mathrm{KB}$ activation by LPS induction of cell environment. ${ }^{23,24}$ Thus, NF- $\kappa B$ activation which had a major role in the survival of $\mathrm{B}$ cells and determines it so did not exceed normal conditions. Then, the role of B cell which can suppress Tregs does not exceed normal conditions and does not leads to the polarization of certain cell subset of Thelper cells, which leads to an inflammatory response. ${ }^{17}$ Flavonoids, such as luteolin contained in tea leaves, can be a factor inhibiting the activation of proinflammatory cytokines production. Resulting in decreased expression of proinflammatory cytokines in macrophages are being treated with luteolin. ${ }^{16}$
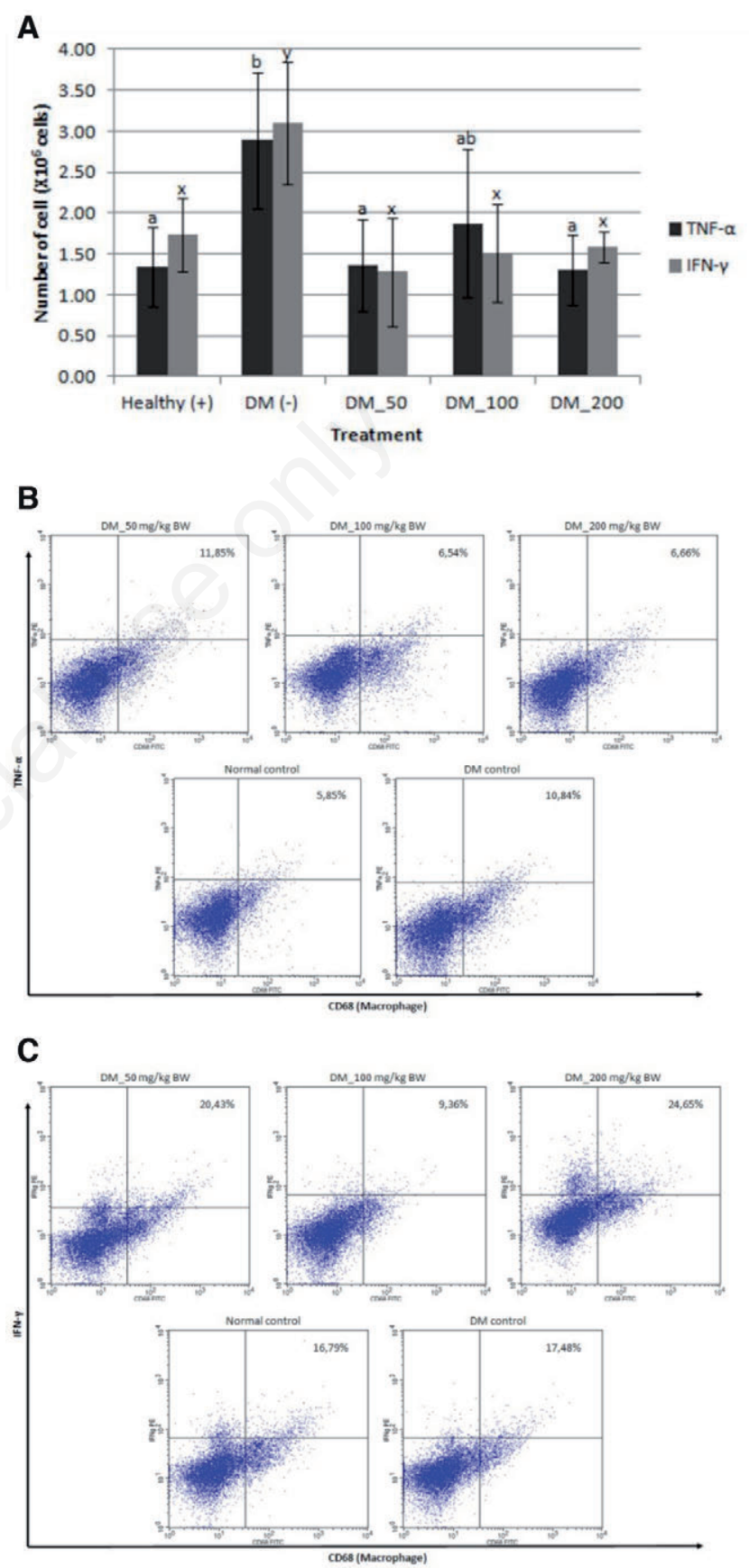

Figure 3. A) Absolute number of macrophage cells with proinflammatory cytokines expression; B) Relative number of macrophage cells with TNF- $\alpha$ expression; C) Relative number of macrophage cells with IFN- $\gamma$ expression. Note: Healthy $(+)=$ normal control; DM (-)=DM control; DM 50=DM with $50 \mathrm{mg}$ EEP/kg BW; DM_100=DM with $100 \mathrm{mg}$ EEP/kg BW; DM_200=DM with $200 \mathrm{mg} \mathrm{EEP/kg} \mathrm{BW.} \mathrm{Data} \mathrm{was} \mathrm{mean} \pm S D$ of each group. A significant difference compared between the letter pairs. The common different letter above the bar indicate significantly different at $\mathrm{P}$-level $=5 \%$. 


\section{Conclusions}

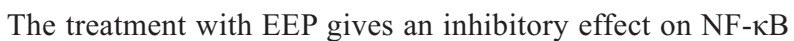
expression, both in macrophage and $\mathrm{B}$ cells, among all dose in this research. Propolis is effective in reducing NF- $\kappa B$ expression in an animal model. However, further study and evaluation is required.

\section{References}

1. Ozougwu JC, Obimba KC, Belonwu CD, Unakalamba CB. The pathogenesis and pathophysiology of type 1 and type 2 diabetes mellitus. J Physiol Pathophysiol 2013;4:46-57.

2. World Health Organization. Global report on diabetes as cited in Diabetes fact sheets of WHO. Geneva: World Health Organization; 2016. Available from http://www.who.int/mediacentre/factsheets/fs312/en/ Accessed: January 2017.

3. Eckmann L, Nebelsiek T, Fingerle AA, et al. Opposing functions of IKK $\beta$ during acute and chronic intestinal inflammation. Proc Natl Acad Sci 2008;105:15058-63.

4. Lawrence T. The nuclear factor NF- $\mathrm{B}$ pathway in inflammation. Cold Spring Harbor Perspect Biol 2009;1:a001651.

5. Kalofoutis C, Piperi C, Kalofoutis A, et al. Type II diabetes mellitus and cardiovascular risk factors: Current therapeutic approaches. Exp Clin Cardiol 2006;12:17-28.

6. Mello BC, Hubinger MD. Antioxidant activity and polyphenol contents in brazilian green propolis extracts prepared with the use of ethanol and water as solvents in different $\mathrm{pH}$ values. Int J Food Sci Technol 2012;47:2510-18.

7. Bankova V, De Castro S, Marcucci M. Propolis: recent advances in chemistry and plant origin. Apidologie 2000;31:3-15.

8. Coneac G, Gafiţanu E, Hădărugă DI, et al. Flavonoid contents of propolis from the West Side of Romania and correlation with the antioxidant activity. Chem Bull Politehnica Univ Timisoara 2008;53:56-60.

9. Barbarić M, Mišković K, Bojić M, et al. Chemical composition of the ethanolic propolis extracts and its effect on HeLa cells. J Ethnopharmacol 2011;135:772-8.

10. Krol W, Scheller S, Czuba Z, et al. Inhibition of neutrophils' chemiluminescence by ethanol extract of propolis (EEP) and its phenolic components. J Ethnopharmacol 1996;55:19-25.
11. American Diabetes Association. Standards of Medical Care in Diabetes. Diabetes Care 2015;38:S8.

12. Lenzen S. The mechanisms of alloxan-and streptozotocininduced diabetes. Diabetologia 2008;51:216-26.

13. Dwijayanti DR, Djati MS, Rifa'i M. The role of VipAlbumin ${ }^{\circledR}$ as an immunostimulatory agent for controlling homeostasis and proliferation of lymphoid cells. Cent Eur J Immunol 2016;41:31-8.

14. del Rio ML, Jones ND, Buhler L, et al. Selective Blockade of Herpesvirus Entry Mediator-B and T Lymphocyte Attenuator Pathway Ameliorates Acute Graft-versus-Host Reaction. J Immunol 2012;188:4885-96.

15. Baker RG, Hayden MS, Ghosh S. NF-кB, inflammation, and metabolic disease. Cell Metabol 2011;13:11-22.

16. Xagorari A, Papapetropoulos A, Mauromatis A, et al. Luteolin inhibits an endotoxin-stimulated phosphorylation cascade and proinflammatory cytokine production in macrophages. J Pharmacol Exp Ther 2001;296:181-7.

17. DeFuria J, Belkina AC, Jagannathan-Bogdan M, et al. B cells promote inflammation in obesity and type 2 diabetes through regulation of T-cell function and an inflammatory cytokine profile. Proc Natl Acad Sci 2013;110:5133-8.

18. Grumont RJ, Strasser A, Gerondakis S. B cell growth is controlled by phosphatidylinosotol 3-kinase-dependent induction of $\mathrm{Rel} / \mathrm{NF}-\kappa \mathrm{B}$ regulated c-myc transcription. Mol Cell 2002;10:1283-94.

19. Stocker H, Hafen E. Genetic control of cell size. Curr Opin Genetics Dev 2000;10:529-35.

20. Rifa'i M, Widodo N. Significance of propolis administration for homeostasis of CD4+ CD25+ immunoregulatory $\mathrm{T}$ cells controlling hyperglycemia. Springerplus 2014;3:526.

21. Rifa'i M. CD4+ CD25+ Regulatory T cells preventing detrimental autoimmune reactions. Open Autoimmun J 2013;5:1-5.

22. Huang CF, Lin SS, Liao PH, Young SC, Yang CC. The immunopharmaceutical effects and mechanisms of herb medicine. Cell Molec Immunol 2008;5:23-31.

23. Ma Q, Kinneer K, Ye J, Chen BJ. Inhibition of nuclear factor $\kappa \mathrm{B}$ by phenolic antioxidants: interplay between antioxidant signaling and inflammatory cytokine expression. Mol Pharmacol 2003;64:211-9.

24. Nair MP, Mahajan S, Reynolds JL, et al. The flavonoid quercetin inhibits proinflammatory cytokine (tumor necrosis factor alpha) gene expression in normal peripheral blood mononuclear cells via modulation of the NF- $\kappa \beta$ system. Clin Vaccine Immunol 2006;13:319-28. 